\title{
SENSORY DESIGN STUDY OF MUSEUM BANK INDONESIA IN ACCOMMODATING VISUALLY IMPAIRED VISITORS
}

\author{
${ }^{1}$ Putri Nadhira Saraswati. ${ }^{2}$ Aldyfra L. Lukman, ST., MT., Ph.D \\ ${ }^{1}$ Student in the Bachelor's (S-1) Study Program in Architecture \\ at Parahyangan Catholic University \\ ${ }^{2}$ Senior lecturer in the Bachelor's (S-1) Study Program in Architecture \\ at Parahyangan Catholic University
}

\begin{abstract}
Museum as an architectural object with its function as an educational and recreational facility is open to public and must be able to be used by all people. Therefore, the design of museums must be accessible for all people, including those with special needs. One of the museums in Indonesia which is considered to be a good work of architecture is the Museum of Bank Indonesia. It receives many visitors from various circles, including people with visual impairments. To accommodate visitors with visual impairments, the Museum of Bank Indonesia must have design features that help them to do activities, despite their limited sense of sight. Through this study, the research aims to find out how physical elements in the Museum of Bank Indonesia accommodates the orientation and mobility of visitors with visual impairments.

This is a qualitative research, with a descriptive discussion. The collected data are the data on physical elements in the Museum of Bank Indonesia and the data on the behavior of visually impaired visitors while doing orientation and mobility in the Museum of Bank Indonesia exhibition area. The data are collected through observation and interview, then analyzed by using a table which elaborates physical elements from technical requirements aspect and sensory design aspect, and how they accommodate visually impaired visitors.

Research shows that some physical elements in the Museum of Bank Indonesia are already adequate in accommodating visually impaired visitors. They able to provide assistance for visually impaired visitors while doing orientation and mobility, as well as gathering information on the museum objects. On the other hand, there are also some physical elements that hinder visually impaired visitors because they don't technically meet the user's needs. Therefore, improvement in the physical elements design is needed, so it can accommodate visitors with visual impairments better.
\end{abstract}

Key Words: museum, visual impairment, Bank Indonesia, universal design, sensory design

\section{TINJAUAN DESAIN SENSORI PADA MUSEUM BANK INDONESIA DALAM MENGAKOMODASI PENGUNJUNG PENYANDANG TUNANETRA}

\author{
${ }^{1}$ Putri Nadhira Saraswati. ${ }^{2}$ Aldyfra L. Lukman, ST., MT., Ph.D \\ ${ }^{1}$ Mahasiswa S1 Program Studi Arsitektur Universitas Katolik Parahyangan. \\ 2 Dosen Pembimbing S1 Program Studi Arsitektur Universitas Katolik Parahyangan.
}

\begin{abstract}
Abstrak- Museum sebagai objek arsitektur dengan fungsi sarana edukasi dan rekreasi bersifat terbuka untuk umum dan harus dapat melayani masyarakat dari berbagai kalangan. Maka dari itu, perancangan museum harus dapat digunakan oleh seluruh kalangan masyarakat, termasuk mereka yang berkebutuhan khusus. Salah satu museum di Indonesia yang dinilai merupakan karya arsitektur yang baik adalah Museum Bank Indonesia. Museum Bank Indonesia pun menerima banyak pengunjung dari berbagai kalangan, di antaranya adalah penyandang tunanetra. Untuk mewadahi pengunjung penyandang tunanetra, Museum Bank Indonesia perlu memiliki fitur desain yang membantu mereka untuk beraktivitas, kendati keterbatasan indra penglihatan yang mereka miliki. Melalui tinjauan ini, penelitian bertujuan untuk mengetahui bagaimana elemen fisik yang bersifat sensorik di Museum Bank Indonesia mengakomodasi orientasi dan mobilitas pengunjung penyandang tunanetra.

Penelitian bersifat kualitatif dengan pembahasan deskriptif. Data yang diambil berupa data elemen fisik Museum Bank Indonesia dan data perilaku pengunjung penyandang tunanetra dalam melakukan orientasi dan mobilitas di area pamer Museum Bank Indonesia. Pengambilan data dilakukan dengan cara observasi dan
\end{abstract}

${ }^{1}$ Corresponding Author: putrinadhiral@gmail.com 
wawancara. Kemudian data dianalisis menggunakan tabel yang menjabarkan elemen fisik dari aspek persyaratan teknis dan aspek desain sensorik, serta bagaimana elemen fisik tersebut mengakomodasi pengunjung penyandang tunanetra.

Hasil penelitian menunjukkan bahwa elemen fisik di Museum Bank ada yang sudah baik dalam mengakomodasi penyandang tunanetra, karena membantu mereka dalam melakukan orientasi dan mobilitas serta menangkap informasi objek museum, ada pula yang menghambat mereka karena secara teknis tidak memenuhi kebutuhan mereka. Oleh karena itu, dibutuhkan peningkatan perancangan elemen fisik sensorik agar dapat lebih baik lagi mengakomodasi pengunjung penyandang tunanetra.

Kata Kunci: museum, tunanetra, Bank Indonesia, desain universal, desain sensori

\section{PENDAHULUAN}

Museum merupakan objek arsitektur yang memiliki fungsi sebagai sarana edukasi dan rekreasi. Berdasarkan definisi dari International Council of Museums (ICOM), museum melayani masyarakat dan terbuka untuk umum. Dengan begitu, perancangan museum harus dapat digunakan oleh seluruh kalangan masyarakat, termasuk mereka yang berkebutuhan khusus. Dalam kata lain, desain universal butuh diaplikasikan pada perancangan museum.

Salah satu museum di Indonesia yang dinilai merupakan karya arsitektur yang baik adalah Museum Bank Indonesia. Sebagai museum yang telah meraih predikat museum terbaik, Museum Bank Indonesia menerima banyak pengunjung dari berbagai kalangan. Data statistik tahun 2019 menunjukan bahwa pengunjung Museum BI berjumlah rata-rata 696 orang per hari ${ }^{2}$, yang di antaranya adalah penyandang tunanetra dari Fellowship of Netra Community. Komunitas tersebut beberapa kali mengadakan program berjudul Blind Adventure di Museum Bank Indonesia, dimana para penyandang tunanetra menjadi pemandu museum bagi orangorang dengan penglihatan normal dalam kondisi mata tertutup.

Untuk mewadahi pengunjung penyandang tunanetra, Museum Bank Indonesia perlu memiliki fitur desain yang membantu mereka untuk beraktivitas, kendati keterbatasan indra penglihatan yang mereka miliki. Keterbatasan indra penglihatan membuat penyandang tunanetra mengandalkan indra lainnya untuk beraktivitas, terutama terkait orientasi dan mobilitas, sehingga fitur desain yang dibutuhkan dapat berupa elemen-elemen fisik yang menjadi stimulan sensorik perangsang indra selain penglihatan. Penelitian ini akan meninjau elemen fisik sensorik di Museum Bank Indonesia yang mengakomodasi pengunjung penyandang tunanetra.

Tujuan dari penelitian adalah untuk mengetahui bagaimana elemen-elemen fisik sensorik di Museum Bank Indonesia mengakomodasi orientasi dan mobilitas pengunjung penyandang tunanetra. Penelitian ini diharapkan dapat memberikan wawasan mengenai perancangan ruang publik yang dapat mengakomodasi penyandang tunanetra, sehingga memberikan kenyamanan, kemudahan, dan keamanan bagi mereka, juga wawasan mengenai desain sensorik yang dapat memperkaya pengalaman ruang bagi pengguna umum.

Penelitian merupakan penelitian kualitatif. Data yang diambil berupa data elemen fisik Museum Bank Indonesia dan data perilaku pengunjung penyandang tunanetra dalam melakukan orientasi dan mobilitas di area pamer Museum Bank Indonesia. Pengambilan data dilakukan dengan cara observasi dan wawancara. Kemudian data dianalisis menggunakan tabel yang menjabarkan elemen fisik dari aspek persyaratan teknis dan aspek desain sensorik, serta bagaimana elemen fisik tersebut mengakomodasi pengunjung penyandang tunanetra.

\footnotetext{
2 https://www.bi.go.id/id/tentang-bi/museum/info/statistik-pengunjung/Default.aspx
} 


\section{KAJIAN TEORI}

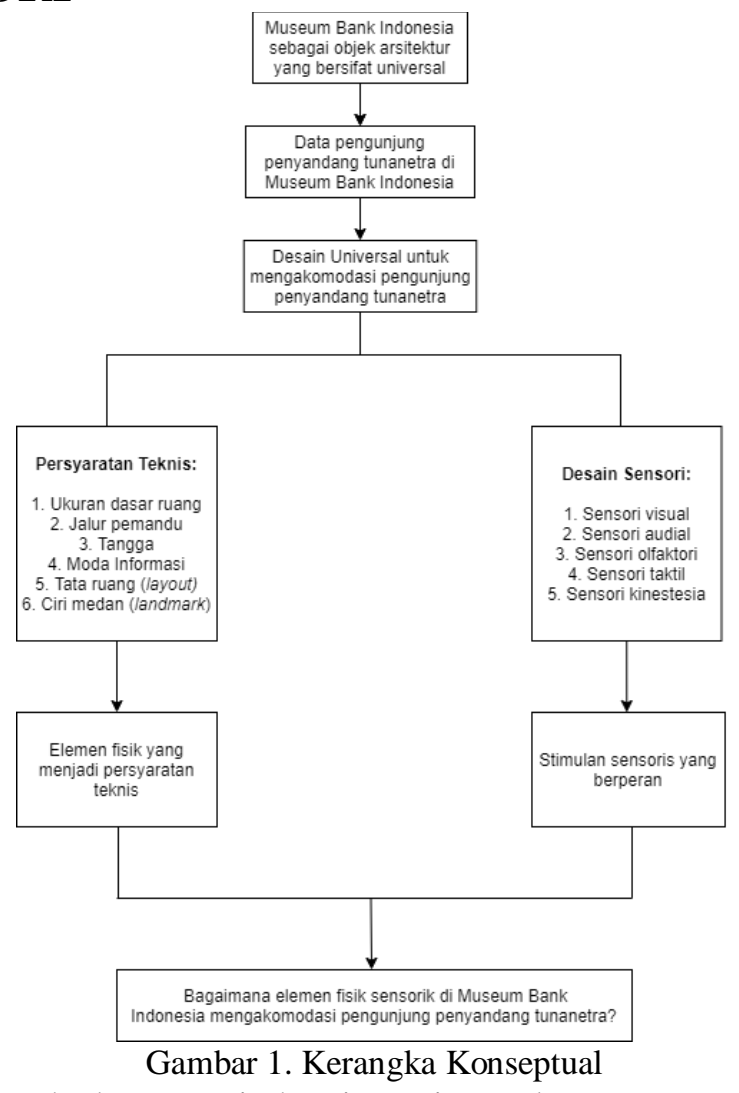

Dasar teori berlandaskan teori desain universal yang memiliki pengertian sebagai desain produk, lingkungan, program, dan layanan yang dapat digunakan oleh semua orang, hingga jangkauan seluas mungkin, tanpa perlu adanya adaptasi. ${ }^{3}$ Kemudian teori tersebut bercabang menjadi dua aspek, yaitu persyaratan teknis dari dan desain sensori.

Teori persyaratan teknis dianggap menjadi bagian dari desain universal karena di Indonesia, ketentuan desain universal dalam arsitektur dibahas di Peraturan Menteri PUPR Nomor 14/PRT/M/2017 tentang Persyaratan Kemudahan Bangunan Gedung. Dalam peraturan tersebut tertera prinsip desain universal, yang kemudian persyaratan teknisnya dijabarkan menjadi elemen ukuran dasar ruang, jalur pemandu, tangga / perbedaan elevasi.

Teori desain sensori dianggap menjadi bagian dari desain universal karena desain sensori dapat mendukung beragam kalangan untuk mengalami ruang dan menerima informasi, kendati keterbatasan kemampuan sensorik yang dimiliki. Teori yang digunakan yaitu milik James J. Gibson yang membagi sistem persepsi menjadi sistem penglihatan yang menerima stimulan visual, sistem pendengaran yang menerima stimulan audial, sistem pengecappenciuman yang menerima stimulan olfaktori, sistem peraba yang menerima stimulan taktil, dan sistem orientasi dasar yang menerima stimulan kinesthesia.

Melihat konteks objek studi dan populasi penelitian, maka digunakan pula teori pendukung yaitu teori museum dan teori mengenai tunanetra beserta orientasi dan mobilitasnya. Dari teori tersebut, didapatkan tambahan poin persyaratan teknis yang harus diperhatikan, yaitu moda informasi dan tata ruang yang merupakan aspek fungsional bangunan museum, dan landmark/clue yang menjadi petunjuk bagi tunanetra dalam melakukan orientasi \& mobilitas.

\footnotetext{
${ }^{3}$ Konferensi PBB tentang Hak Penyandang Disabilitas tahun 2006
} 


\section{METODE PENELITIAN}

Pengumpulan data diawali dengan mengobservasi elemen fisik apa saja yang ada di Museum Bank Indonesia, dengan mengacu kepada teori aspek persyaratan teknis dan desain sensori. Kemudian mengobservasi perilaku orientasi dan mobilitas penyandang tunanetra di area pamer Museum Bank Indonesia. Setelah itu dilakukan pula wawancara untuk mengetahui lebih dalam mengenai bagaimana elemen fisik sensorik di Museum Bank Indonesia mengakomodasi orientasi dan mobilitas penyandang tunanetra.

Analisis dilakukan dengan membagi pembahasan akomodasi penyandang tunanetra berdasarkan poin-poin persyaratan teknisnya. Pada masing-masing poin, data fisik yang ada diklasifikasikan lagi berdasarkan stimulan sensorik yang berperan. Kemudian dianalisis apakah elemen fisik tersebut membantu, menghambat, atau netral (tidak memberi pengaruh) terhadap kegiatan orientasi, mobilitas, dan menangkap informasi.

Setelah melakukan kajian analisis, dilakukan penyusunan sintesis yang menyimpulkan pengaruh masing-masing elemen fisik terhadap orientasi dan mobilitas penyandang tunanetra.

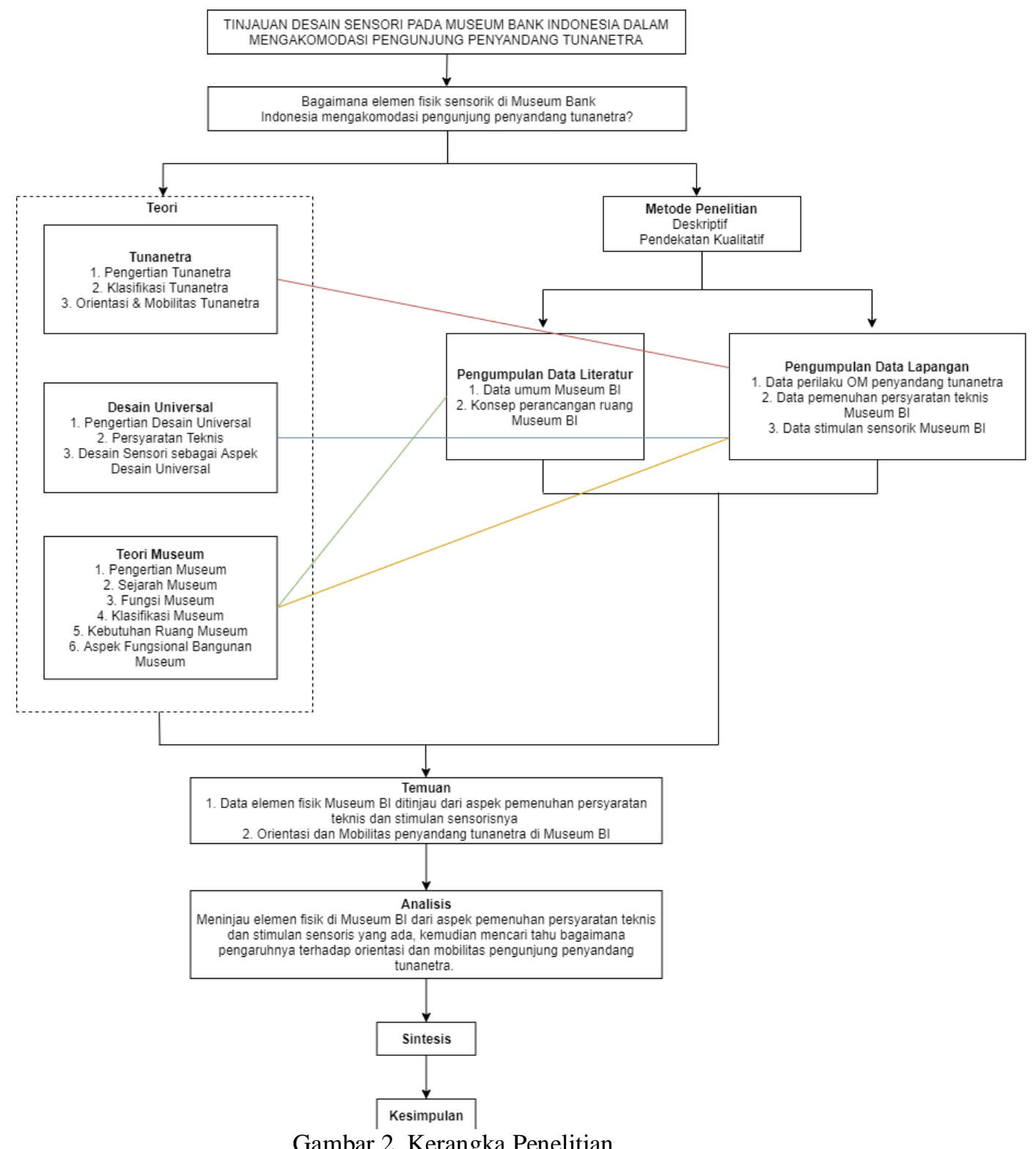




\section{ANALISIS}

Data hasil observasi dan wawancara disusun berdasarkan pembagian ruang pada area pamer museum dan diurutkan berdasarkan alurnya. Kemudian data tersebut dianalisis dengan pembahasan yang terbagi menjadi akomodasi masing-masing poin persyaratan teknis.

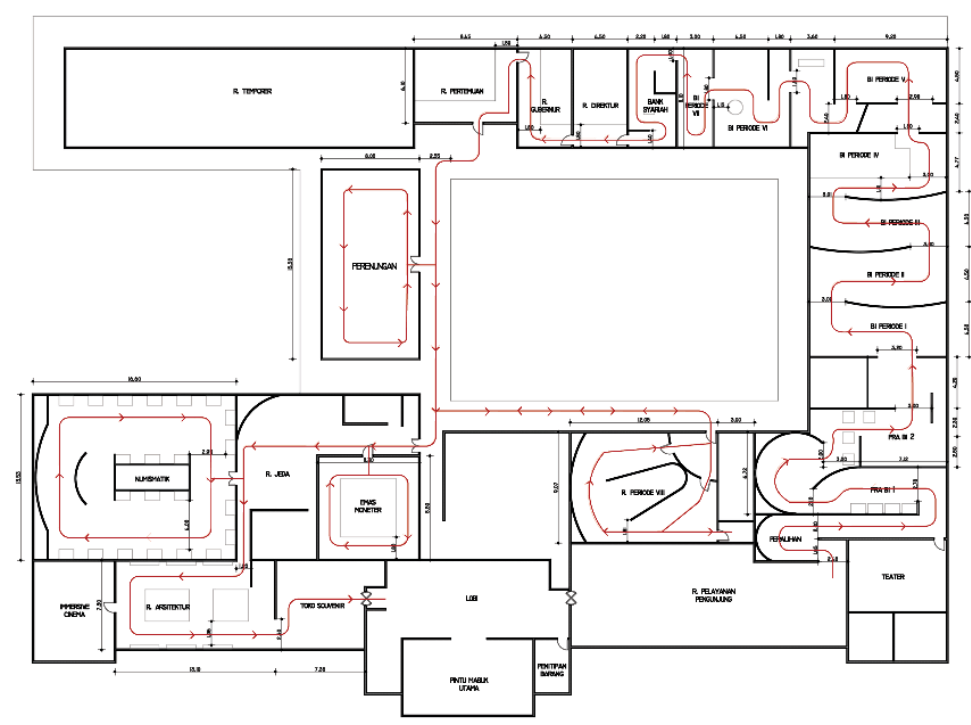

Gambar 3. Denah Alur Museum Bank Indonesia

Tabel 1. Daftar Ruang pada Area Pamer Museum Bank Indonesia

\begin{tabular}{|c|c|c|c|}
\hline No. & Ruang & Elemen Fisik Sensorik & Gambar \\
\hline 1 & $\begin{array}{l}\text { Peralihan } \\
\text { (ruang } \\
\text { proyektor) }\end{array}$ & $\begin{array}{l}\text { Tata ruang loop, ramp, tirai } \\
\text { plastik, minim cahaya (hanya ada } \\
\text { motion graphic) }\end{array}$ & \\
\hline 2 & $\begin{array}{l}\text { Peralihan } \\
\text { (ruang kisi- } \\
\text { kisi kayu) }\end{array}$ & $\begin{array}{l}\text { Tata ruang liner, indirect light, } \\
\text { kisi-kisi kayu di dinding }\end{array}$ & \\
\hline 3 & Pra BI 1 & $\begin{array}{l}\text { Tata ruang linier, material lantai } \\
\text { kayu, display material kayu \& } \\
\text { akrilik }\end{array}$ & \\
\hline 4 & Pra BI 2 & $\begin{array}{l}\text { Tata ruang kurvalinier, material } \\
\text { lantai kayu menjadi keramik, } \\
\text { audio dome, display di dinding, } \\
\text { display di lantai bermaterial kaca, } \\
\text { display logo BI }\end{array}$ & \\
\hline 5 & BI Periode I & $\begin{array}{l}\text { Tata ruang kurvalinier, celah pada } \\
\text { dinding, material lantai kermaik } \\
\text { doff, railing kaca, display tulisan } \\
\text { dinding, TV \& audio dome }\end{array}$ & \\
\hline
\end{tabular}




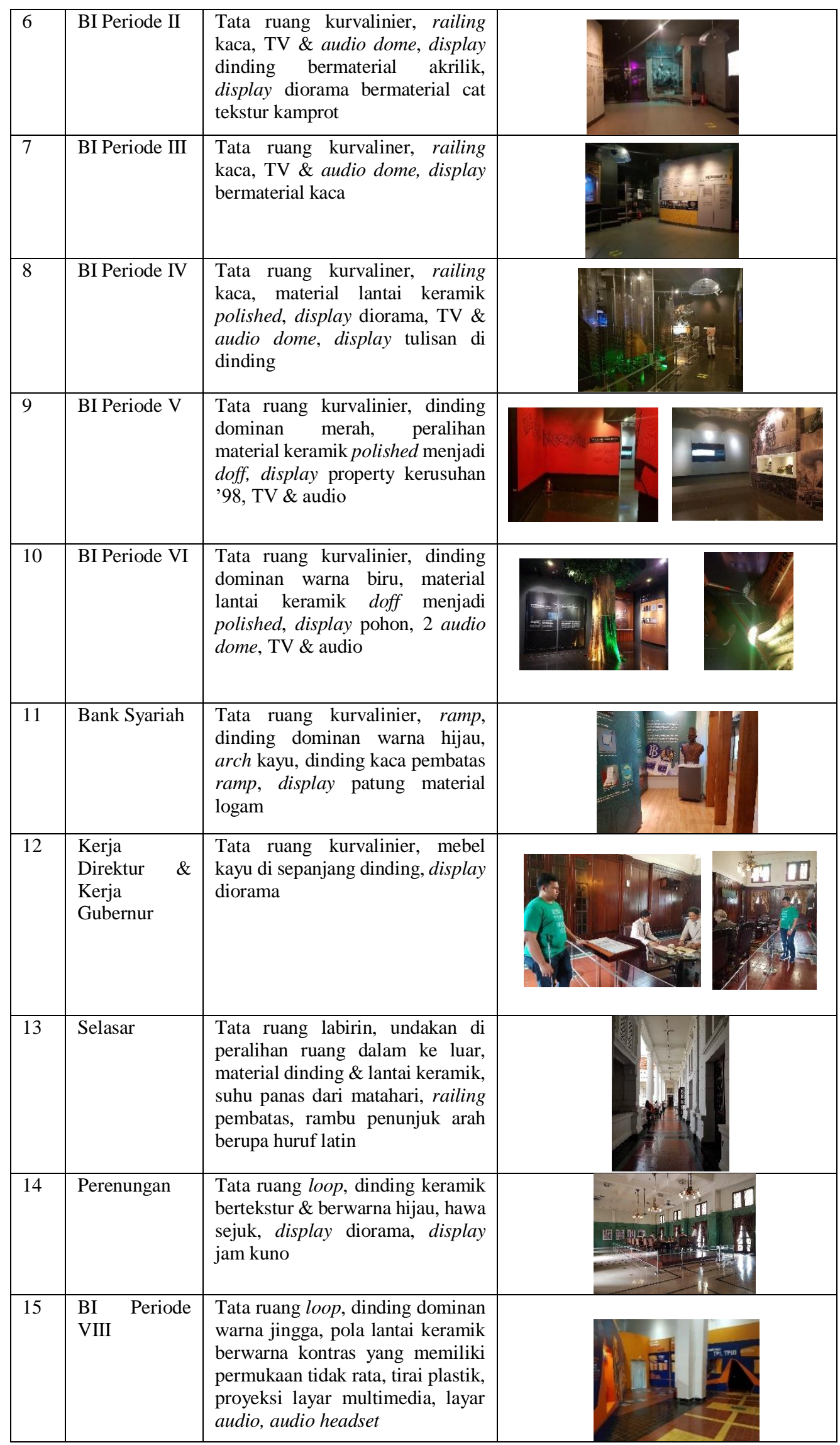




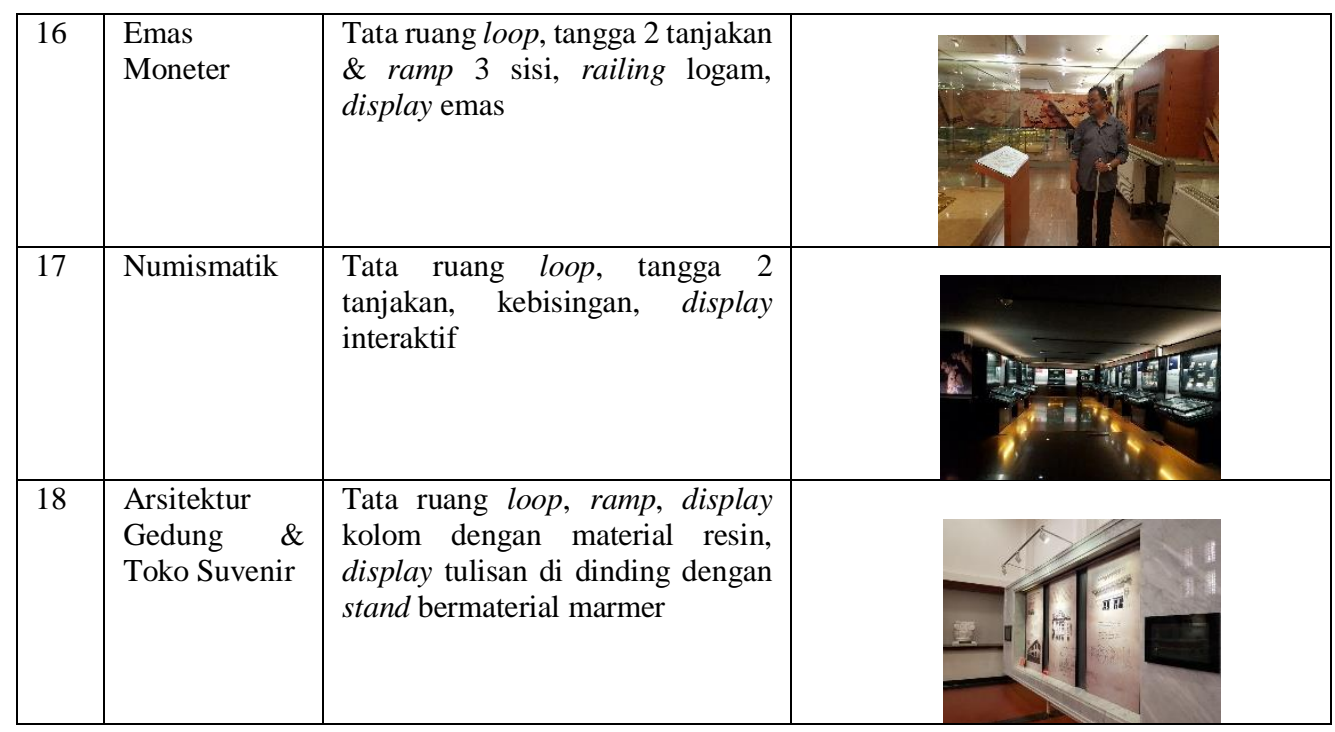

\subsection{AKOMODASI PENYANDANG TUNANETRA DARI ASPEK UKURAN DASAR RUANG}

Tabel 2. Akomodasi Penyandang Tunanetra dari Aspek Ukuran Dasar Ruang

\begin{tabular}{|c|c|c|c|c|c|c|c|c|c|c|c|}
\hline \multirow{3}{*}{$\begin{array}{c}\text { Stimulan } \\
\text { yang } \\
\text { Berperan }\end{array}$} & \multirow{3}{*}{$\begin{array}{c}\text { Ukuran } \\
\text { Dasar } \\
\text { Ruang }\end{array}$} & \multirow{3}{*}{$\begin{array}{c}\text { Keterangan Data } \\
\text { Lapangan }\end{array}$} & \multicolumn{9}{|c|}{ Akomodasi Penyandang Tunanetra } \\
\hline & & & \multicolumn{3}{|c|}{$\begin{array}{l}\text { Low vision - } \\
\text { familiar }\end{array}$} & \multicolumn{3}{|c|}{$\begin{array}{l}\text { Total blind- } \\
\text { non familiar }\end{array}$} & \multicolumn{3}{|c|}{$\begin{array}{l}\text { Total blind- } \\
\text { familiar }\end{array}$} \\
\hline & & & O & $\mathbf{M}$ & $\mathbf{I}$ & $\mathbf{O}$ & $\mathbf{M}$ & $\mathbf{I}$ & $\mathbf{O}$ & $\mathbf{M}$ & $\mathbf{I}$ \\
\hline \multirow[t]{2}{*}{ Kinestesia } & \multirow{2}{*}{$\begin{array}{l}\text { Jangkauan } \\
\text { ke samping }\end{array}$} & $<120 \mathrm{~cm}$ & $\mathrm{X}$ & $\mathrm{X}$ & $\mathrm{N}$ & $\mathrm{X}$ & $\mathrm{X}$ & $\mathrm{N}$ & $\mathrm{X}$ & $\mathrm{X}$ & $\mathrm{N}$ \\
\hline & & $120 \mathrm{~cm}-300 \mathrm{~cm}$ & $\sqrt{ }$ & $\sqrt{ }$ & $\mathrm{N}$ & $\sqrt{ }$ & $\sqrt{ }$ & $\mathrm{N}$ & $\sqrt{ }$ & $\sqrt{ }$ & $\mathrm{N}$ \\
\hline
\end{tabular}

Keterangan:

$\mathrm{O}:$ dalam kegiatan Orientasi

M : dalam kegiatan Mobilitas

I : dalam menangkap Informasi $\sqrt{ }:$ membantu

$\mathrm{X}$ : menghambat

$\mathrm{N}$ : netral (tidak memberi pengaruh)

\subsection{AKOMODASI PENYANDANG TUNANETRA DARI ASPEK JALUR PEMANDU}

Tabel 3. Akomodasi Penyandang Tunanetra dari Aspek Jalur Pemandu

\begin{tabular}{|c|c|c|c|c|c|c|c|c|c|c|c|}
\hline \multirow{3}{*}{$\begin{array}{l}\text { Stimulan } \\
\text { yang } \\
\text { Berperan }\end{array}$} & \multirow{3}{*}{$\begin{array}{c}\text { Jalur } \\
\text { Pemandu }\end{array}$} & \multirow{3}{*}{$\begin{array}{c}\text { Keterangan Data } \\
\text { Lapangan }\end{array}$} & \multicolumn{9}{|c|}{ Akomodasi Penyandang Tunanetra } \\
\hline & & & \multicolumn{3}{|c|}{$\begin{array}{l}\text { Low vision - } \\
\text { familiar }\end{array}$} & \multicolumn{3}{|c|}{$\begin{array}{l}\text { Total blind- } \\
\text { non familiar }\end{array}$} & \multicolumn{3}{|c|}{$\begin{array}{l}\text { Total blind- } \\
\text { familiar }\end{array}$} \\
\hline & & & $\mathbf{O}$ & $\mathbf{M}$ & $\mathbf{I}$ & O & $\mathbf{M}$ & $\mathbf{I}$ & $\mathbf{O}$ & $\mathbf{M}$ & I \\
\hline Taktil & Tidak ada & Tidak ada & $\mathrm{N}$ & $\mathrm{N}$ & $\mathrm{N}$ & $\mathrm{X}$ & $\mathrm{X}$ & $\mathrm{X}$ & $\mathrm{N}$ & $\mathrm{N}$ & $\mathrm{N}$ \\
\hline
\end{tabular}

\subsection{AKOMODASI PENYANDANG TUNANETRA DARI ASPEK TANGGA/PERBEDAAN ELEVASI}

Tabel 4. Akomodasi Penyandang Tunanetra dari Aspek Tangga/Perbedaan Elevasi Akomodasi Penyandang Tunanetra 


\begin{tabular}{|c|c|c|c|c|c|c|c|c|c|c|c|}
\hline \multirow[t]{2}{*}{$\begin{array}{c}\text { Stimulan } \\
\text { yang } \\
\text { Berperan }\end{array}$} & \multirow[t]{2}{*}{$\begin{array}{c}\text { Tangga / } \\
\text { Perbedaan } \\
\text { Elevasi }\end{array}$} & \multirow[t]{2}{*}{$\begin{array}{l}\text { Keterangan Data } \\
\text { Lapangan }\end{array}$} & \multicolumn{3}{|c|}{$\begin{array}{l}\text { Low vision- } \\
\text { familiar }\end{array}$} & \multicolumn{3}{|c|}{$\begin{array}{l}\text { Total blind } \\
\text { - non } \\
\text { familiar }\end{array}$} & \multicolumn{3}{|c|}{$\begin{array}{l}\text { Total blind- } \\
\text { familiar }\end{array}$} \\
\hline & & & O & $\mathbf{M}$ & I & O & $\mathbf{M}$ & $\mathbf{I}$ & O & $\mathbf{M}$ & I \\
\hline \multirow[t]{4}{*}{ Kinestesia } & Ramp & & $\sqrt{ }$ & $\sqrt{ }$ & $\mathrm{N}$ & $\sqrt{ }$ & $\sqrt{ }$ & $\mathrm{N}$ & $\sqrt{ }$ & $\sqrt{ }$ & $\mathrm{N}$ \\
\hline & $\begin{array}{l}\text { Undakan di } \\
\text { peralihan } \\
\text { ruang dalam } \\
\text { \& ruang } \\
\text { luar }\end{array}$ & & $\mathrm{N}$ & $\mathrm{N}$ & $\mathrm{N}$ & $\mathrm{N}$ & $\mathrm{N}$ & $\mathrm{N}$ & $\mathrm{X}$ & $X$ & $\mathrm{~N}$ \\
\hline & $\begin{array}{l}\text { Tangga } 2 \\
\text { tanjakan } \\
\text { dan ramp } 3 \\
\text { sisi } \\
\end{array}$ & & $\mathrm{N}$ & $\mathrm{N}$ & $\mathrm{N}$ & $\mathrm{X}$ & $\mathrm{X}$ & $\mathrm{N}$ & $X$ & $\mathrm{X}$ & $\mathrm{N}$ \\
\hline & $\begin{array}{l}\text { Tangga } 2 \\
\text { tanjakan }\end{array}$ & & $\mathrm{N}$ & $\mathrm{N}$ & $\mathrm{N}$ & $\mathrm{N}$ & $\mathrm{N}$ & $\mathrm{N}$ & $X$ & $\mathrm{X}$ & $\mathrm{N}$ \\
\hline
\end{tabular}

\subsection{AKOMODASI PENYANDANG TUNANETRA DARI ASPEK TATA RUANG}

Tabel 5. Akomodasi Penyandang Tunanetra dari Aspek Tata Ruang

\begin{tabular}{|c|c|c|c|c|c|c|c|c|c|c|c|}
\hline \multirow{3}{*}{$\begin{array}{l}\text { Stimulan } \\
\text { yang } \\
\text { Berperan }\end{array}$} & \multirow{3}{*}{$\begin{array}{c}\text { Jalur } \\
\text { Pemandu }\end{array}$} & \multirow{3}{*}{$\begin{array}{c}\text { Keterangan Data } \\
\text { Lapangan }\end{array}$} & \multicolumn{9}{|c|}{ Akomodasi Penyandang Tunanetra } \\
\hline & & & \multicolumn{3}{|c|}{$\begin{array}{l}\text { Low vision - } \\
\text { familiar }\end{array}$} & \multicolumn{3}{|c|}{$\begin{array}{l}\text { Total blind- } \\
\text { non familiar }\end{array}$} & \multicolumn{3}{|c|}{$\begin{array}{l}\text { Total blind-- } \\
\text { familiar }\end{array}$} \\
\hline & & & $\mathbf{O}$ & $\mathbf{M}$ & $\mathbf{I}$ & $\mathbf{O}$ & $\mathbf{M}$ & $\mathbf{I}$ & $\mathbf{O}$ & $\mathbf{M}$ & $\mathbf{I}$ \\
\hline \multirow[t]{6}{*}{ Kinestesia } & \multirow[t]{2}{*}{ Loop } & $\begin{array}{l}\text { Peletakan objek di } \\
\text { tengah ruang }\end{array}$ & $\mathrm{N}$ & $\mathrm{N}$ & $\mathrm{N}$ & $\sqrt{ }$ & $\mathrm{N}$ & $\mathrm{N}$ & $\mathrm{N}$ & $\mathrm{N}$ & $\mathrm{N}$ \\
\hline & & $\begin{array}{l}\text { Akses keluar-masuk } \\
\text { yang sama membentuk } \\
\text { alur melingkar }\end{array}$ & $\mathrm{N}$ & $\mathrm{N}$ & $\mathrm{N}$ & $\mathrm{N}$ & $\mathrm{N}$ & $\mathrm{N}$ & $\mathrm{N}$ & $\mathrm{N}$ & $\mathrm{N}$ \\
\hline & \multirow[t]{3}{*}{ Linier } & Berupa lorong & $\mathrm{N}$ & $\mathrm{N}$ & $\mathrm{N}$ & $\sqrt{ }$ & $\sqrt{ }$ & $\mathrm{N}$ & $\mathrm{N}$ & $\mathrm{N}$ & $\mathrm{N}$ \\
\hline & & $\begin{array}{l}\text { Kurvalinier, mengikuti } \\
\text { tatanan display }\end{array}$ & $\mathrm{N}$ & $\mathrm{N}$ & $\mathrm{N}$ & $\mathrm{X}$ & $\mathrm{X}$ & $\mathrm{N}$ & $\mathrm{N}$ & $\mathrm{N}$ & $\mathrm{N}$ \\
\hline & & $\begin{array}{l}\text { Dinding lengkung } \\
\text { bercelah }\end{array}$ & $\mathrm{N}$ & $\mathrm{N}$ & $\mathrm{N}$ & $\mathrm{X}$ & $\mathrm{X}$ & $\mathrm{N}$ & $\mathrm{X}$ & $\mathrm{X}$ & $\mathrm{N}$ \\
\hline & Labirin & $\begin{array}{l}\text { Terdapat percabangan } \\
\text { alur }\end{array}$ & $\mathrm{X}$ & $\mathrm{N}$ & $\mathrm{N}$ & $X$ & $X$ & $\mathrm{~N}$ & $\mathrm{~N}$ & $\mathrm{~N}$ & $\mathrm{~N}$ \\
\hline
\end{tabular}

\subsection{AKOMODASI PENYANDANG TUNANETRA DARI ASPEK LANDMARK DAN/ATAU CLUE}

Tabel 6. Akomodasi Penyandang Tunanetra dari Aspek Landmark dan/atau Clue

\begin{tabular}{|c|c|c|c|c|c|c|c|c|c|c|c|}
\hline \multirow{3}{*}{$\begin{array}{c}\text { Stimulan } \\
\text { yang } \\
\text { Berperan }\end{array}$} & \multirow{3}{*}{$\begin{array}{c}\text { Landmark / } \\
\text { Clue }\end{array}$} & \multirow{3}{*}{$\begin{array}{c}\text { Keterangan Data } \\
\text { Lapangan }\end{array}$} & \multicolumn{9}{|c|}{ Akomodasi Penyandang Tunanetra } \\
\hline & & & \multicolumn{3}{|c|}{$\begin{array}{l}\text { Low vision - } \\
\text { familiar }\end{array}$} & \multicolumn{3}{|c|}{$\begin{array}{l}\text { Total blind } \\
- \text { non } \\
\text { familiar }\end{array}$} & \multicolumn{3}{|c|}{$\begin{array}{l}\text { Total blind } \\
\text { - familiar }\end{array}$} \\
\hline & & & $\mathbf{O}$ & $\mathbf{M}$ & $\mathbf{I}$ & $\mathbf{O}$ & $\mathbf{M}$ & $\mathbf{I}$ & $\mathbf{O}$ & $\mathbf{M}$ & $\mathbf{I}$ \\
\hline \multirow[t]{3}{*}{ Visual } & \multirow[t]{3}{*}{ Pencahayaan } & Minim cahaya & $\mathrm{N}$ & $\mathrm{N}$ & $\mathrm{N}$ & $\mathrm{N}$ & $\mathrm{N}$ & $\mathrm{N}$ & $\mathrm{N}$ & $\mathrm{N}$ & $\mathrm{N}$ \\
\hline & & Indirect light & $\mathrm{N}$ & $\mathrm{N}$ & $\mathrm{N}$ & $\mathrm{N}$ & $\mathrm{N}$ & $\mathrm{N}$ & $\mathrm{N}$ & $\mathrm{N}$ & $\mathrm{N}$ \\
\hline & & Pencahayaan alami & $\mathrm{N}$ & $\mathrm{N}$ & $\mathrm{N}$ & $\mathrm{N}$ & $\mathrm{N}$ & $\mathrm{N}$ & $\mathrm{N}$ & $\mathrm{N}$ & $\mathrm{N}$ \\
\hline
\end{tabular}




\begin{tabular}{|c|c|c|c|c|c|c|c|c|c|c|c|}
\hline & $\begin{array}{l}\text { Warna } \\
\text { Dinding }\end{array}$ & $\begin{array}{l}\text { Perbedaan warna } \\
\text { dinding sesuai zona } \\
\text { pameran }\end{array}$ & $\sqrt{ }$ & $\sqrt{ }$ & $\sqrt{ }$ & $\mathrm{N}$ & $\mathrm{N}$ & $\mathrm{N}$ & $\mathrm{N}$ & $\mathrm{N}$ & $\mathrm{N}$ \\
\hline & $\begin{array}{l}\text { Pola lantai } \\
\text { keramik }\end{array}$ & & $\sqrt{ }$ & $\sqrt{ }$ & $\sqrt{ }$ & $\mathrm{N}$ & $\mathrm{N}$ & $\mathrm{N}$ & $\mathrm{N}$ & $\mathrm{N}$ & $\mathrm{N}$ \\
\hline \multirow[t]{2}{*}{ Audial } & Kebisingan & $\begin{array}{l}\text { Kebisingan dari } \\
\text { pengunjung lain }\end{array}$ & $\mathrm{N}$ & $\mathrm{N}$ & $\mathrm{N}$ & $\mathrm{N}$ & $\mathrm{N}$ & $\mathrm{N}$ & $\mathrm{X}$ & $\mathrm{X}$ & $\mathrm{X}$ \\
\hline & $\begin{array}{l}\text { Audio pada } \\
\text { display }\end{array}$ & & $\mathrm{N}$ & $\mathrm{N}$ & $\sqrt{ }$ & $\sqrt{ }$ & $\mathrm{N}$ & $\sqrt{ }$ & $\mathrm{N}$ & $\mathrm{N}$ & $\sqrt{ }$ \\
\hline \multirow[t]{3}{*}{ Olfaktori } & Tirai plastik & & $\mathrm{N}$ & $\mathrm{N}$ & $\mathrm{N}$ & $\mathrm{N}$ & $\mathrm{N}$ & $\mathrm{N}$ & $\sqrt{ }$ & $\mathrm{N}$ & $\mathrm{N}$ \\
\hline & $\begin{array}{l}\text { Mebel kayu di } \\
\text { sepanjang } \\
\text { dinding }\end{array}$ & & $\mathrm{N}$ & $\mathrm{N}$ & $\mathrm{N}$ & $\sqrt{ }$ & $\mathrm{N}$ & $\sqrt{ }$ & $\mathrm{N}$ & $\mathrm{N}$ & $\mathrm{N}$ \\
\hline & $\begin{array}{l}\text { Display uang } \\
\text { di Ruang } \\
\text { Numismatik }\end{array}$ & & $\mathrm{N}$ & $\mathrm{N}$ & $\mathrm{N}$ & $\sqrt{ }$ & $\mathrm{N}$ & $\sqrt{ }$ & $\mathrm{N}$ & $\mathrm{N}$ & $\mathrm{N}$ \\
\hline \multirow[t]{5}{*}{ Taktil } & Tirai plastik & & $\mathrm{N}$ & $\mathrm{N}$ & $\mathrm{N}$ & $\mathrm{N}$ & $\sqrt{ }$ & $\mathrm{N}$ & $\mathrm{N}$ & $\mathrm{N}$ & $\mathrm{N}$ \\
\hline & $\begin{array}{l}\text { Perbedaan } \\
\text { material lantai }\end{array}$ & & $\sqrt{ }$ & $\sqrt{ }$ & $\mathrm{N}$ & $\sqrt{ }$ & $\sqrt{ }$ & $\mathrm{N}$ & $\sqrt{ }$ & $\sqrt{ }$ & $\mathrm{N}$ \\
\hline & Railing & & $\sqrt{ }$ & $\sqrt{ }$ & $\mathrm{N}$ & $\sqrt{ }$ & $\sqrt{ }$ & $\mathrm{N}$ & $\sqrt{ }$ & $\sqrt{ }$ & $\mathrm{N}$ \\
\hline & $\begin{array}{l}\text { Tekstur } \\
\text { material } \\
\text { dinding }\end{array}$ & & $\mathrm{N}$ & $\mathrm{N}$ & $\mathrm{N}$ & $\sqrt{ }$ & $\sqrt{ }$ & $\mathrm{N}$ & $\sqrt{ }$ & $\sqrt{ }$ & $\mathrm{N}$ \\
\hline & $\begin{array}{l}\text { Arch kayu } \\
\text { sebagai } \\
\text { pembatas } \\
\text { ruangan }\end{array}$ & & $\mathrm{N}$ & $\mathrm{N}$ & $\mathrm{N}$ & $\mathrm{X}$ & $\mathrm{X}$ & $\mathrm{N}$ & $\mathrm{X}$ & $\mathrm{X}$ & $\mathrm{N}$ \\
\hline \multirow[t]{3}{*}{ Taktil } & $\begin{array}{l}\text { Dinding kaca } \\
\text { sebagai } \\
\text { pembatas } \\
\text { ramp }\end{array}$ & & $\mathrm{N}$ & $\mathrm{N}$ & $\mathrm{N}$ & $\sqrt{ }$ & $\sqrt{ }$ & $\mathrm{N}$ & $\sqrt{ }$ & $\sqrt{ }$ & $\mathrm{N}$ \\
\hline & $\begin{array}{l}\text { Mebel kayu di } \\
\text { sepanjang } \\
\text { dinding }\end{array}$ & & $\mathrm{N}$ & $\mathrm{N}$ & $\mathrm{N}$ & $\sqrt{ }$ & $\sqrt{ }$ & $\mathrm{N}$ & $\sqrt{ }$ & $\sqrt{ }$ & $\mathrm{N}$ \\
\hline & Suhu & & $\mathrm{N}$ & $\mathrm{N}$ & $\mathrm{N}$ & $\sqrt{ }$ & $\mathrm{N}$ & $\mathrm{N}$ & $\sqrt{ }$ & $\mathrm{N}$ & $\mathrm{N}$ \\
\hline \multirow[t]{3}{*}{ Kinestesia } & Railing & & $\sqrt{ }$ & $\sqrt{ }$ & $\mathrm{N}$ & $\sqrt{ }$ & $\sqrt{ }$ & $\mathrm{N}$ & $\sqrt{ }$ & $\sqrt{ }$ & $\mathrm{N}$ \\
\hline & $\begin{array}{l}\text { Arch kayu } \\
\text { sebagai } \\
\text { pembatas } \\
\text { ruangan }\end{array}$ & & $\mathrm{N}$ & $\mathrm{N}$ & $\mathrm{N}$ & $\mathrm{X}$ & $\mathrm{X}$ & $\mathrm{N}$ & $\mathrm{X}$ & $\mathrm{X}$ & $\mathrm{N}$ \\
\hline & $\begin{array}{l}\text { Dinding kaca } \\
\text { sebagai } \\
\text { pembatas } \\
\text { ramp }\end{array}$ & & $\mathrm{N}$ & $\mathrm{N}$ & $\mathrm{N}$ & $\sqrt{ }$ & $\sqrt{ }$ & $\mathrm{N}$ & $\sqrt{ }$ & $\sqrt{ }$ & $\mathrm{N}$ \\
\hline
\end{tabular}

\subsection{AKOMODASI PENYANDANG TUNANETRA DARI ASPEK MODA INFORMASI}

Tabel 7. Akomodasi Penyandang Tunanetra dari Aspek Moda Informasi

\begin{tabular}{|c|c|c|c|c|c|c|c|c|c|c|c|}
\hline \multirow{3}{*}{$\begin{array}{c}\text { Stimulan } \\
\text { yang } \\
\text { Berperan }\end{array}$} & \multirow{3}{*}{$\begin{array}{c}\text { Jalur } \\
\text { Pemandu }\end{array}$} & \multirow{3}{*}{$\begin{array}{c}\text { Keterangan Data } \\
\text { Lapangan }\end{array}$} & \multicolumn{9}{|c|}{ Akomodasi Penyandang Tunanetra } \\
\hline & & & & $\begin{array}{l}\text { visi } \\
\text { iliar }\end{array}$ & & & fam & $\begin{array}{l}\text { nd } \\
\text { liar }\end{array}$ & & & lind - \\
\hline & & & $\mathbf{O}$ & $\mathbf{M}$ & I & $\mathbf{O}$ & $\mathbf{M}$ & $\mathbf{I}$ & 0 & & $\mathbf{I}$ \\
\hline
\end{tabular}




\begin{tabular}{|c|c|c|c|c|c|c|c|c|c|c|c|}
\hline \multirow[t]{3}{*}{ Visual } & $\begin{array}{l}\text { Display } \\
\text { tulisan }\end{array}$ & $\begin{array}{l}\text { Hanya tersedia tulisan } \\
\text { latin, tidak ada huruf } \\
\text { braille }\end{array}$ & $\mathrm{N}$ & $\mathrm{N}$ & $\mathrm{X}$ & $\mathrm{N}$ & $\mathrm{N}$ & $\mathrm{X}$ & $\mathrm{N}$ & $\mathrm{N}$ & $\mathrm{X}$ \\
\hline & $\begin{array}{l}\text { Display } \\
\text { diorama } \\
\text { (yang tidak } \\
\text { dapat } \\
\text { disentuh } \\
\text { karena ada } \\
\text { pembatas) }\end{array}$ & & $\sqrt{ }$ & $\mathrm{N}$ & $\sqrt{ }$ & $\mathrm{N}$ & $\mathrm{N}$ & $\mathrm{N}$ & $\mathrm{N}$ & $\mathrm{N}$ & $\mathrm{N}$ \\
\hline & $\begin{array}{l}\text { Display } \\
\text { interaktif }\end{array}$ & $\begin{array}{l}\text { Tidak terdapat } \\
\text { petunjuk penggunaan } \\
\text { interaksi display. } \\
\text { Untuk memahami } \\
\text { informasi display } \\
\text { hanya bisa dengan cara } \\
\text { melihat. }\end{array}$ & $\mathrm{N}$ & $\mathrm{N}$ & $\mathrm{N}$ & $\mathrm{N}$ & $\mathrm{N}$ & $\mathrm{N}$ & $\mathrm{N}$ & $\mathrm{N}$ & $\mathrm{N}$ \\
\hline \multirow{3}{*}{ Visual } & TV & & $\mathrm{N}$ & $\mathrm{N}$ & $\mathrm{N}$ & $\mathrm{N}$ & $\mathrm{N}$ & $\mathrm{N}$ & $\mathrm{N}$ & $\mathrm{N}$ & $\mathrm{N}$ \\
\hline & $\begin{array}{l}\text { Rambu } \\
\text { penunjuk } \\
\text { arah }\end{array}$ & $\begin{array}{l}\text { Hanya tersedia tulisan } \\
\text { latin, tidak ada huruf } \\
\text { braille }\end{array}$ & $\mathrm{N}$ & $\mathrm{N}$ & $\mathrm{N}$ & $\mathrm{N}$ & $\mathrm{N}$ & $\mathrm{N}$ & $\mathrm{N}$ & $\mathrm{N}$ & $\mathrm{N}$ \\
\hline & $\begin{array}{l}\text { Proyeksi } \\
\text { layar } \\
\text { multimedia }\end{array}$ & & $\mathrm{N}$ & $\mathrm{N}$ & $\mathrm{N}$ & $\mathrm{N}$ & $\mathrm{N}$ & $\mathrm{N}$ & $\mathrm{N}$ & $\mathrm{N}$ & $\mathrm{N}$ \\
\hline \multirow[t]{3}{*}{ Audial } & Audio dome & & $\mathrm{N}$ & $\mathrm{N}$ & $\sqrt{ }$ & $\sqrt{ }$ & $\mathrm{N}$ & $\sqrt{ }$ & $\mathrm{N}$ & $\mathrm{N}$ & $\sqrt{ }$ \\
\hline & $\begin{array}{l}\text { Audio dari } \\
\text { speaker }\end{array}$ & & $\mathrm{N}$ & $\mathrm{N}$ & $\sqrt{ }$ & $\sqrt{ }$ & $\mathrm{N}$ & $\sqrt{ }$ & $\mathrm{N}$ & $\mathrm{N}$ & $\sqrt{ }$ \\
\hline & $\begin{array}{l}\text { Audio dari } \\
\text { headset }\end{array}$ & & $\mathrm{N}$ & $\mathrm{N}$ & $\sqrt{ }$ & $\mathrm{N}$ & $\mathrm{N}$ & $\sqrt{ }$ & $\mathrm{N}$ & $\mathrm{N}$ & $\mathrm{N}$ \\
\hline Olfaktori & Tidak ada & Tidak ada & $\mathrm{N}$ & $\mathrm{N}$ & $\mathrm{N}$ & $\mathrm{N}$ & $\mathrm{N}$ & $\mathrm{N}$ & $\mathrm{N}$ & $\mathrm{N}$ & $\mathrm{N}$ \\
\hline \multirow[t]{3}{*}{ Taktil } & $\begin{array}{l}\text { Tekstur } \\
\text { display }\end{array}$ & $\begin{array}{l}\text { - Material kayu } \\
\text { - Material akrilik } \\
\text { - Material kaca } \\
\text { - Material emas } \\
\text { - Material logam } \\
\text { - Material marmer } \\
\text { - Material resin } \\
\text { - Material cat }\end{array}$ & $\mathrm{N}$ & $\mathrm{N}$ & $\sqrt{ }$ & $\sqrt{ }$ & $\mathrm{N}$ & $\sqrt{ }$ & $\sqrt{ }$ & $\mathrm{N}$ & $\sqrt{ }$ \\
\hline & \multirow[t]{2}{*}{$\begin{array}{l}\text { Display } \\
\text { interaktif }\end{array}$} & $\begin{array}{l}\text { Dengan kaca pembesar } \\
\text { untuk melihat uang }\end{array}$ & $\mathrm{N}$ & $\mathrm{N}$ & $\mathrm{N}$ & $\mathrm{N}$ & $\mathrm{N}$ & $\mathrm{N}$ & $\mathrm{N}$ & $\mathrm{N}$ & $\mathrm{N}$ \\
\hline & & Berupa laci vertikal & $\mathrm{N}$ & $\mathrm{N}$ & $\mathrm{N}$ & $\mathrm{N}$ & $\mathrm{N}$ & $\mathrm{N}$ & $\mathrm{N}$ & $\mathrm{N}$ & $\mathrm{N}$ \\
\hline Kinestesia & Tidak ada & Tidak ada & $\mathrm{N}$ & $\mathrm{N}$ & $\mathrm{N}$ & $\mathrm{N}$ & $\mathrm{N}$ & $\mathrm{N}$ & $\mathrm{N}$ & $\mathrm{N}$ & $\mathrm{N}$ \\
\hline
\end{tabular}

\subsubsection{SINTESIS}

Tabel 8. Sintesis

\begin{tabular}{|l|l|l|l|}
\hline \multicolumn{1}{|c|}{ Aspek } & $\begin{array}{c}\text { Stimulan } \\
\text { yang } \\
\text { Berperan }\end{array}$ & \multicolumn{1}{|c|}{$\begin{array}{c}\text { Akomodasi Penyandang } \\
\text { Tunanetra }\end{array}$} \\
\hline $\begin{array}{l}\text { Ukuran } \\
\text { Dasar } \\
\text { Ruang }\end{array}$ & Kinestesia & $\begin{array}{l}\text { Jangkauan ke samping dengan } \\
\text { dimensi di atas 120 cm sudah } \\
\text { memadai untuk mobilitas, } \\
\text { sedangkan dimensi jangkauan ke }\end{array}$ & $\begin{array}{l}\text { Meskipun persyaratan } \\
\text { teknis untuk jangkauan ke } \\
\text { samping adalah 90 cm, } \\
\text { sebaiknya dibuat lebih } \\
\text { lebar untuk kondisi ramai. }\end{array}$ \\
\hline
\end{tabular}




\begin{tabular}{|c|c|c|c|}
\hline & & $\begin{array}{llll}\text { samping kurang dari } 120 & \mathrm{~cm} \\
\text { menghambat mobilitas. } & & \\
\end{array}$ & \\
\hline $\begin{array}{l}\text { Jalur } \\
\text { Pemandu }\end{array}$ & Taktil & $\begin{array}{l}\text { Tidak adanya jalur pemandu } \\
\text { membuat penyandang tunanetra } \\
\text { yang non familiar dengan } \\
\text { lingkungannya, } \\
\text { berorientasi. Peran jalur pemanditan } \\
\text { ada yang digantikan oleh } \\
\text { peralihan material lantai. Namun } \\
\text { di area dengan alur bercabang } \\
\text { yang justru paling membutuhkan, } \\
\text { tidak tersedia. }\end{array}$ & $\begin{array}{l}\text { Jalur pemandu dibutuhkan } \\
\text { di sepanjang alur museum. } \\
\text { Jalur pemandu tidak harus } \\
\text { berupa guiding block atau } \\
\text { warning block, tapi bisa } \\
\text { pula dengan pola } \\
\text { penyusunan tekstur } \\
\text { material lantai. }\end{array}$ \\
\hline Aspek & $\begin{array}{c}\text { Stimulan } \\
\text { yang } \\
\text { Berperan }\end{array}$ & $\begin{array}{c}\text { Akomodasi Penyandang } \\
\text { Tunanetra }\end{array}$ & Evaluasi \\
\hline $\begin{array}{l}\text { Tangga/ } \\
\text { Perbedaan } \\
\text { Elevasi }\end{array}$ & Kinestesia & $\begin{array}{l}\text { Ramp yang diletakan di } \\
\text { perbedaan elevasi antarruang } \\
\text { membantu penyandang tunanetra } \\
\text { untuk melakukan mobilitas. } \\
\text { Namun, dimensi landasan ramp } \\
\text { yang terlalu sempit dapat } \\
\text { membahayakan. - Perbedaan } \\
\text { elevasi antarruang yang berupa } \\
\text { undakan menghambat karena } \\
\text { berisiko membuat tergelincir. }\end{array}$ & $\begin{array}{l}\text { Sebaiknya ramp diletakkan } \\
\text { di perbedaan elevasi } \\
\text { antarruang dengan } \\
\text { memperhatikan dimensi } \\
\text { landasannya untuk segi } \\
\text { keamanan saat mobilitas. }\end{array}$ \\
\hline Tata Ruang & Kinestesia & $\begin{array}{l}\text { - Tata ruang linier yang sederhana } \\
\text { paling tepat untuk orientasi \& } \\
\text { mobilitas penyandang tunanetra } \\
\text { - Tata ruang loop sederhana, } \\
\text { cukup mudah dilalui } \\
\text { - Tata ruang labirin paling sulit } \\
\text { dilalui, apalagi jika ada } \\
\text { percabangan alur dan tidak ada } \\
\text { petunjuk. }\end{array}$ & $\begin{array}{l}\text { Tata ruang yang paling } \\
\text { tepat untuk tunanetra } \\
\text { adalah yang sederhana, } \\
\text { seperti linier. Apabila } \\
\text { menggunakan tata ruang } \\
\text { selain linier, misal loop } \\
\text { atau labirin, harus } \\
\text { dilengkapi oleh petunjuk } \\
\text { yang jelas (seperti jalur } \\
\text { pemandu). }\end{array}$ \\
\hline \multirow[t]{3}{*}{$\begin{array}{l}\text { Landmark/ } \\
\text { Clue }\end{array}$} & Visual & $\begin{array}{l}\text { Bagi penyandang low vision, } \\
\text { warna yang kontras membantunya } \\
\text { untuk mengidentifikasi ruang dan } \\
\text { mengarahkan alur. }\end{array}$ & $\begin{array}{l}\text { Perbedaan warna dinding } \\
\text { yang kontras sesuai zona } \\
\text { pameran serta pola dan } \\
\text { warna keramik lantai yang } \\
\text { kontras cukup baik untuk } \\
\text { membantu orientasi } \\
\text { penyandang low vision. }\end{array}$ \\
\hline & Audial & $\begin{array}{l}\text { - Audio pada display membantu } \\
\text { mengarahkan penyandang } \\
\text { tunanetra saat melakukan OM. } \\
\text { - Kebisingan saat kondisi ramai } \\
\text { membuat penyandang tunanetra } \\
\text { bingung untuk menentukan } \\
\text { orientasinya. }\end{array}$ & $\begin{array}{l}\text { Dapat diaplikasikan desain } \\
\text { akustik pada permukaan } \\
\text { bidang di area pamer untuk } \\
\text { mengurangi kebisingan. }\end{array}$ \\
\hline & Olfaktori & $\begin{array}{l}\text { Tanpa desain yang disengaja, } \\
\text { perabot dengan bau khas } \\
\text { membantu penyandang tunanetra } \\
\text { untuk mengidentifikasikan ruang. }\end{array}$ & $\begin{array}{lr}\text { Peningkatan } & \text { dapat } \\
\text { dilakukan } & \text { dengan } \\
\text { menggunakan material } \\
\text { interior alami } & \text { atau } \\
\text { meletakkan } & \text { elemen } \\
\text { dekorasi dengan bau khas. }\end{array}$ \\
\hline
\end{tabular}




\begin{tabular}{|c|c|c|c|}
\hline \multirow[b]{2}{*}{$\begin{array}{l}\text { Landmark/ } \\
\text { Clue }\end{array}$} & Taktil & $\begin{array}{l}\text { Stimulan taktil banyak yang } \\
\text { berpengaruh terhadap OM } \\
\text { penyandang tunanetra, yang } \\
\text { signifikan di antaranya yaitu } \\
\text { perbedaan material lantai, dinding } \\
\& \text { railing (terutama yang } \\
\text { bertekstur), perbedaan suhu } \\
\text { kontras, dan suhu sejuk yang } \\
\text { meninggalkan kesan lebih baik. }\end{array}$ & $\begin{array}{l}\text { Peran landmark yang } \\
\text { bersifat taktil sudah cukup } \\
\text { baik dalam } \\
\text { mengakomodasi orientasi } \\
\text { dan mobilitas pengunjung } \\
\text { penyandang tunanetra. }\end{array}$ \\
\hline & Kinestesia & $\begin{array}{l}\text { - Dinding dan railing membantu } \\
\text { untuk memberi petunjuk arah, } \\
\text { serta menjadi pembatas untuk segi } \\
\text { keamanan. } \\
\text { - Stimulan kinestesia yang } \\
\text { dimensi jangkauan ke sampingnya } \\
\text { terlalu sempit malah menghambat } \\
\text { mobilitas. }\end{array}$ & $\begin{array}{l}\text { Adanya dinding \& railing } \\
\text { sudah cukup membantu } \\
\text { OM penyandang tunanetra. } \\
\text { Hanya di beberapa area } \\
\text { perlu diperhatikan dimensi } \\
\text { jangkauan ke samping, } \\
\text { agar tidak malah } \\
\text { menghambat. }\end{array}$ \\
\hline \multirow[t]{5}{*}{$\begin{array}{l}\text { Moda } \\
\text { Informasi }\end{array}$} & Visual & $\begin{array}{l}\text { - Akses untuk moda informasi } \\
\text { berbentuk visual sangat terbatas, } \\
\text { dan sebagian tidak ada bentuk } \\
\text { alternatifnya. Display tulisan tidak } \\
\text { dilengkapi huruf braille, display } \\
\text { diorama tidak dapat disentuh, } \\
\text { display interaktif pun tidak } \\
\text { memiliki petunjuk penggunaan } \\
\text { untuk tunanetra, sehingga } \\
\text { informasi tidak sampai secara } \\
\text { maksimal. } \\
\text { - Informasi penunjuk arah juga } \\
\text { tidak memadai. Hanya tersedia } \\
\text { rambu tulisan latin. }\end{array}$ & $\begin{array}{l}\text { Moda informasi visual } \\
\text { seharusnya memiliki } \\
\text { bentuk alternatif yang } \\
\text { dapat diakses oleh } \\
\text { penyandang tunanetra, } \\
\text { seperti dalam bentuk taktil } \\
\text { (tulisan braille) atau bentuk } \\
\text { audial. }\end{array}$ \\
\hline & Audial & $\begin{array}{l}\text { Bentuk moda informasi alternatif } \\
\text { yang paling membantu adalah } \\
\text { audial, yaitu berupa audio dome } \\
\text { yang memberi gambaran umum di } \\
\text { tiap zona pameran. }\end{array}$ & $\begin{array}{l}\text { Audio dome cukup } \\
\text { membantu sebagai moda } \\
\text { informasi } \\
\text { penunjuk arah. }\end{array}$ \\
\hline & Olfaktori & $\begin{array}{l}\text { Tidak ada moda informasi berupa } \\
\text { stimulan olfaktori. }\end{array}$ & $\begin{array}{l}\text { Stimulan olfaktori dapat } \\
\text { digunakan untuk } \\
\text { memperkaya penangkapan } \\
\text { informasi, misal display } \\
\text { rempah di Ruang Pra BI. }\end{array}$ \\
\hline & Taktil & $\begin{array}{l}\text { Display yang dapat disentuh } \\
\text { membantu penyandang tunanetra } \\
\text { untuk mengidentifikasikan ruang } \\
\text { karena pengalaman tersebut lebih } \\
\text { meninggalkan kesan. Namun dari } \\
\text { segi informasi, mereka merasa } \\
\text { butuh penjelasan lebih lanjut. }\end{array}$ & $\begin{array}{l}\text { Seharusnya display yang } \\
\text { dapat disentuh dilengkapi } \\
\text { oleh penjelasan, seperti } \\
\text { berupa tulisan braille atau } \\
\text { audio, sehingga } \\
\text { penyandang tunanetra } \\
\text { dapat lebih memahami } \\
\text { informasi objek tersebut. }\end{array}$ \\
\hline & Kinestesia & Tidak ada & Tidak ada \\
\hline
\end{tabular}

\subsection{KESIMPULAN}


Hasil penelitian menunjukan bahwa desain sensori pada Museum Bank Indonesia mengakomodasi pengunjung penyandang tunanetra dalam melakukan orientasi dan mobilitas serta dalam menangkap informasi objek museum melalui elemen fisik yang terdapat di dalamnya. Elemen fisik tersebut terbagi dalam beberapa aspek, yaitu ukuran dasar ruang, tangga / perbedaan elevasi, tata ruang, landmark / clue, dan moda informasi. Di antaranya ada yang keberadaannya membantu penyandang tunanetra, ada pula yang menghambat karena secara teknis tidak memenuhi kebutuhan pengguna.

Secara keseluruhan, Museum Bank Indonesia mengakomodasi pengunjung penyandang tunanetra dengan baik pada aspek perbedaan elevasi berupa ramp, tata ruang yang sederhana, landmark dalam bentuk stimulan visual, taktil, audial, dan kinesthesia, serta moda informasi dalam bentuk stimulan audial, dan taktil. Di samping itu, dibutuhkan peningkatan untuk mengakomodasi pengunjung penyandang tunanetra pada aspek ukuran dasar ruang untuk lebar koridor yang sempit, perbedaan elevasi yang berupa undakan-undakan, aspek penyediaan jalur pemandu, aspek tata ruang yang kompleks, aspek landmark yang berupa stimulan olfaktori, dan bentuk alternatif untuk moda informasi visual.

\subsubsection{PENUTUP}

Peningkatan yang dapat dilakukan untuk aspek ukuran dasar ruang adalah memperlebar jalur sirkulasi yang dimensi jangkauan ke sampingnya kurang dari $120 \mathrm{~cm}$. Peningkatan tersebut dapat dilakukan di bagian yang dindingnya berupa partisi dan display bersifat temporer. Pada aspek jalur pemandu, peningkatkan dapat dilakukan dengan meletakkan guiding block dan warning block, terutama di alur yang bercabang, atau dengan memberikan material penutup lantai yang berbeda pada titik percabangan alur. Pada aspek tata ruang yang kompleks, tata ruang tidak butuh diganti, melainkan peningkatan dapat cukup dilakukan dengan memberi jalur pemandu. Pada aspek landmark, stimulan olfaktori dapat ditingkatkan dengan meletakan perabot atau elemen dekorasi dengan bau khas, sehingga memberi informasi tambahan kepada penyandang tunanetra, baik untuk orientasi dan mobilitas, maupun untuk memahami infomrasi objek museum. Pada aspek moda informasi, peningkatan dapat dilakukan dengan menambahkan moda informasi alternatif, berupa taktil (tulisan braille), audial, dan olfaktori.

Secara umum, perancangan museum sebagai ruang publik harus memperhatikan kebutuhan setiap penggunanya, termasuk penyandang disabilitas. Dalam konteks penyandang tunanetra, untuk memberi akomodasi yang baik untuk orientasi dan mobilitas mereka bisa dengan memperhatikan stimulan sensori pada perancangan elemen fisik, karena mereka mengandalkan stimulan sensori selain visual untuk menangkap informasi. Selain untuk penyandang tunanetra, perancangan yang memperhatikan stimulan sensori juga dapat memperkaya pengalaman ruang bagi pengguna pada umumnya.

Penulis berharap bahwa makalah ini dapat berkontribusi pada penelitian arsitektur untuk penyandang tunanetra, juga terkait desain universal dan desain sensori. Selain itu, semoga penelitian ini dapat bermanfaat untuk pembaca dan menginspirasi penelitianpenelitian yang berikutnya.

\section{DAFTAR PUSTAKA}

\section{Buku}

HILL, E., \& PONDER, P. (1976). Orientation and Mobility Techniques: A Guide of The Practitioner. New York: American Foundation for the Blind. 
HOOPER-GREENHILL, E. (1992). Museums and the shaping of knowledge. London: Routledge

IN LUPTON, E., IN LIPPS, A., \& COOPER-HEWITT MUSEUM,. (2018). The senses: Design beyond vision.

JACOBSON, W. (1993). The Art and Science of Teaching Orientation and Mobility to Persons with Visual Impairments. New York: American Foundation for the Blind.

LEITNER, B. (1978). Sound:Space. New York: New York University Press.

LEONE, M., \& LITTLE, B. (2007). Artifacts as expressions of society and culture.

Subversive genealogy and the value of history. In B. Carbonell (Ed.), Museum studies. An anthology of contexts (pp. 362-374). Malden, MA: Blackwell Publishing.

LOWENFELD, B. (1981). Blindness and Blind People. New York: Amer Foundation for the Blind.

MALNAR, JOY AND FRANK VODVARKA. (2004). Sensory Design. Minneapolis: University of Minnesota Press.

MATTHEW, GEOFF. (1991). Museum and Art Galleries (Development and Design Guide). Oxford: Butterworth Architecture.

NAVARRETE, T., \& MACKENZIE OWEN, J. (2016). The Museum as Information Space: Metadata and Documentation. In K. J. Borowiecki, N. Forbes, \& A. Fresa (Eds.), Cultural Heritage in a Changing World (pp. 111-123). Switzerland: Springer International Publishing.

PALASMAA, J. (1996). The Eyes of The Skin: Architecture and the Senses. Chichester: Wiley-Academy.

\section{Jurnal}

COLENBRANDER, A., \& FRANCISCO, S. (1862). The COLENBRANDER Low Vision Measurement System. Reading, 2.

DEVLIEGER P. \& FROYEN H. Blindness/city: a disability dialect, Devlieger P. et al. (eds), Blindness and the multi-sensorial city, 2006, Garant, Antwerpen, pp.17-38

FRASER, JULIE \& GUTWIN, CARL. (2001). A Framework of Assistive Pointers for Low Vision Users.

GEDUNG BANK INDONESIA : jejak arsitektur dalam menggapai kemakmuran negeri. (2012). Jakarta: Bank Indonesia.

HERSSENS, J., \& HEYLIGHEN, A. (2008). Haptics and Vision in Architecture. August. HEYLIGHEN, A., \& HERSSENS, J. (2014). Designerly Ways of Not Knowing: What Designers Can Learn about Space from People Who are Blind. Journal of Urban Design, 19(3), 317-332.

HEYLIGHEN, A., DOREN, C. VAN, \& VERMEERSCH, P. (1993). Architecture through disability experience.

LONG, R. ., \& GIUDICE, N. . (2010). Establishing and maintaining orientation for mobility. Foundations of Orientation and Mobility, 1(August), 45-62.

MICHAEL SOUTHWORTH. (1969). The Sonic Environment of Cities. Environment and Behaviour.

PALAASMA, J. (1994). An Architecture of the Seven Senses. In Questions of Perception: Phenomenology of Architecture (pp. 40-49).

SCHAMBURECK, ERIN \& PARKINSON, SHARRAN. (2015). Design for Sight: A Typology System for Low-Vision Design Factors. Journal of Interior Design. THIEL, P. (1961). A Sequence-Experience Notation: For Architectural and Urban Spaces. The Town Planning Review, 32(1), 33-52. 
TJAHJOPURNOMO, R. (2011). Sejarah Permuseuman Di Indonesia. Journal of Chemical Information and Modeling, 53(9), 1689-1699

VERMEERSCH, P. W., \& HEYLIGHEN, A. (2011). Blindness and multi-sensoriality in architecture. The case of Carlos Mourão Pereira. ARCC/EAAE 2010 International Conference on Architectural Research Location, May 2014.

VERMEERSCH, P. W., STRICKFADEN, M., HERSSENS, J., \& HEYLIGHEN, A. (2009).

Architects and visually impaired people: Analyzing two ways of talking. DS 58-1:

Proceedings of ICED 09, the 17th International Conference on Engineering Design, 1(August 2014), 495-506.

WEST, C. K., \& GIBSON, J. J. (1969). The Senses Considered as Perceptual Systems. Journal of Aesthetic Education, 3(1), 142.

\section{Skripsi}

YOHANNES, A. (2001). Kajian Orientasi dan Mobilitas Kaum Tunanetra terhadap Lingkungan dengan Objek Studi PSBN Wyata Guna, Jl. Padjajaran, Bandung. Bandung:

Universitas Katolik Parahyangan

\section{Peraturan}

Peraturan Menteri Pekerjaan Umum dan Perumahan Rakyat Nomor 14/PRT/M/2017

tentang Persyaratan Kemudahan Bangunan Gedung

\section{Situs Web}

https://www.britannica.com/topic/museum-cultural-institution\#ref341407

https://people.emich.edu/tli/Courses/SPVI368/LandmarkClues.html

https://icom.museum/en/activities/standards-guidelines/museum-definition/

https://visionaware.org/everyday-living/essential-skills/an-introduction-to-orientation-and-

mobility-skills/

https://www.who.int/news-room/fact-sheets/detail/blindness-and-visual-impairment 